\title{
Organocatalyzed Decarboxylation of Naturally Occurring Cinnamic Acids: Potential Role in Flavoring Chemicals Production
}

\author{
Virginia Aldabalde ${ }^{1 \#}$, Mariela Risso ${ }^{\# \#}$, María Lucía Derrudi ${ }^{1}$, Federico Geymonat ${ }^{1}$, Gustavo Seoane ${ }^{1}$, \\ Daniela Gamenara ${ }^{1}$, Patricia Saenz-Méndez ${ }^{1,2^{*}}$ \\ ${ }^{1}$ Grupo de Fisicoquímica Orgánica y Bioprocesos, Facultad de Química, UdelaR, Montevideo, Uruguay \\ ${ }^{2}$ Computational Chemistry and Biology Group, Facultad de Química, UdelaR, Montevideo, Uruguay \\ E-mail:"psaenz@fq.edu.uy \\ Received June 26, 2011; revised August 15, 2011; accepted September 17, 2011
}

\begin{abstract}
The mechanism and the final outcome of the Knoevenagel-Doebner reaction are discussed. The condensation reaction between different hydroxy-substituted aromatic aldehydes and malonic acid is performed using piperidine as organocatalyst. The key role of the catalyst is clearly pointed out during the decarboxylation of ferulic acid, without the use of a strong decarboxylating agent, leading to a 4-vinylphenol derivative. Based on the results obtained, the studied pathway may be important in the understanding of vinylphenol production during malting and brewing of wheat and barley grains. Finally, changing the solvent of the reaction from pyridine to water in the Knoevenagel-Doebner reaction of 4-hydroxybenzaldehydes, dimerization of resulting styrene derivatives is observed. These results can be of interest also in the field of food chemistry, since cinnamic acids are frequently found in fruits and vegetables used for human consumption.
\end{abstract}

Keywords: $\alpha, \beta$-Unsaturated Carboxylic Acids, Decarboxylation, Vinylphenols, Organocatalysis, Knoevenagel

\section{Introduction}

$\alpha, \beta$-Unsaturated carboxylic acids are versatile compounds which allow the access to a variety of synthetic intermediates as well as natural products, such as lignin related structures (Figure 1) [1].

Lignin is a component of the cell wall in vascular plants. Its structure involves a variety of different covalent bonds result of the oxidative coupling of aromatic alcohols derived from hydroxycinnamic acids [2]. There is an increasing interest in its structural study due to its potential utilization as renewable raw material in the chemical industry.

Within a research program devoted to the use of $\alpha, \beta$ unsaturated carboxylic acids to prepare lignans as well as high added value building blocks, the synthesis of cinnamic acid derivatives through a Knoevenagel-Doebner reaction was performed $[3,4]$. The Knoevenagel condensation of aldehydes and malonic acid is generally promoted by bases, such as pyridine and piperidine, yielding

\# Both authors contributed equally. the corresponding $\alpha, \beta$-unsaturated carboxylic acid, under organocatalytic conditions [5]. Organocatalysis has become a field of great importance within organic synthesis, allowing the development of widely applicable reactions while avoiding the use of metal catalysts [6-9].

In this context, we condensed different aromatic aldehydes with malonic acid, using piperidine as organocatalyst and pyridine as solvent $[10,11]$. In most cases, the reaction lead to the corresponding $\alpha, \beta$-unsaturated carboxylic acid in very good yields (results not shown). However, when vanillin (4-hydroxy-3-methoxybenzaldehyde) was employed as electrophile, the formation of 2-methoxy-4-vinylphenol 1a, instead of ferulic acid ( $(E)$ 3-(4-hydroxy-3-methoxyphenyl)-2-propenoic acid) 2a, was observed (Figure 2).

This useful transformation was reported in 2005 and since then, some aspects of the outcome of the reaction were described [12,13].

4-Vinylphenols are natural products widely distributed in plants [14-17]. Moreover, such intermediates are also employed as building blocks for the preparation of 


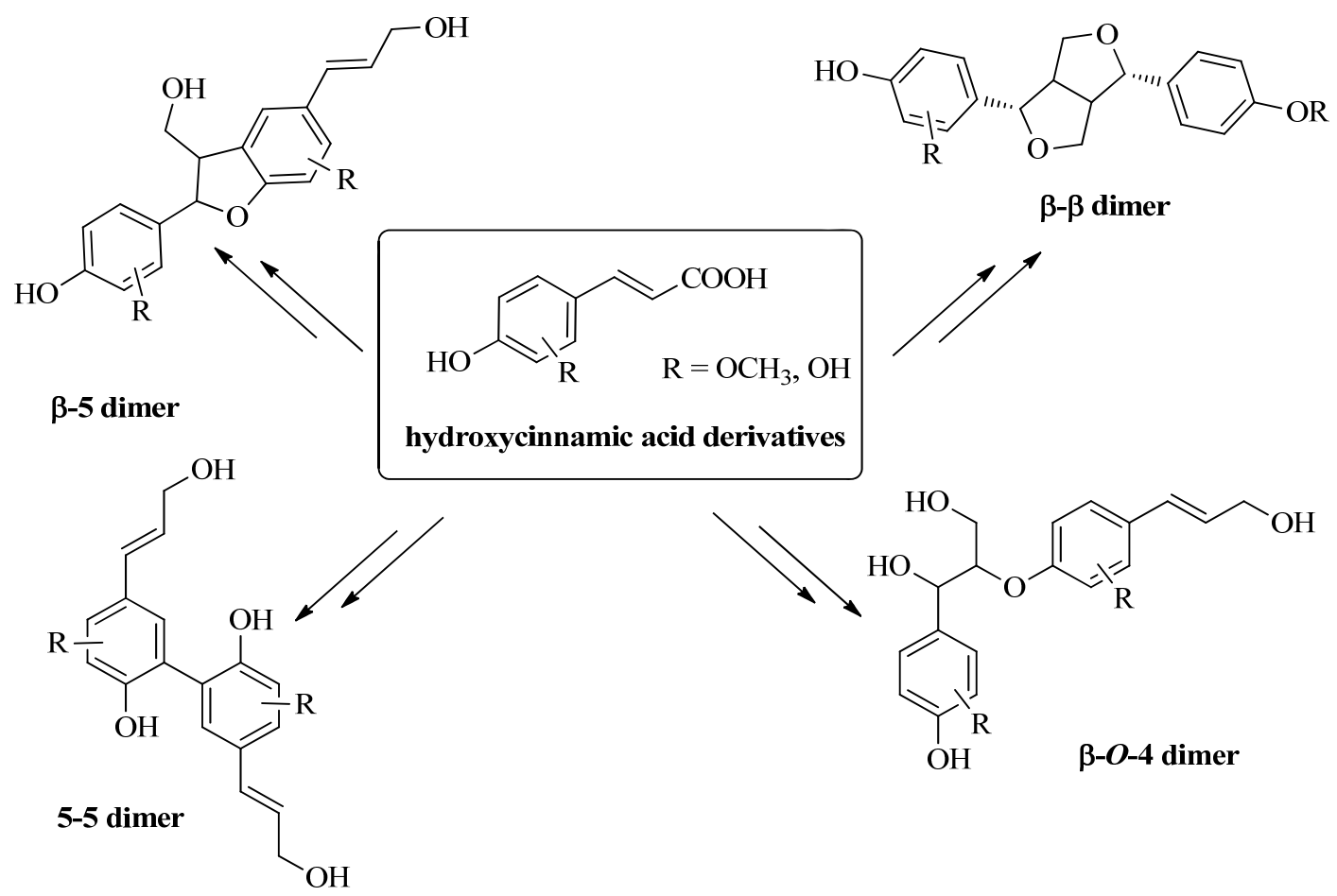

Figure 1. $\alpha, \beta$-Unsaturated carboxylic acids as precursors of lignin models.<smiles>COc1cc(C=O)ccc1O</smiles>

vanillin

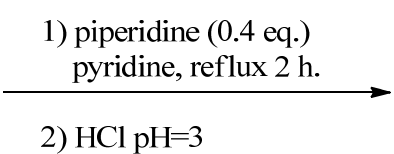

2) $\mathrm{HCl} \mathrm{pH}=3$<smiles>C=Cc1ccc(O)c(OC)c1</smiles>

$1 \mathbf{a}$<smiles>COc1cc(/C=C/C(=O)O)ccc1O</smiles>

$2 a$

Figure 2. Organocatalyzed conversion of vanillin into 2-methoxy-4-vinylphenol 1a.

polymers and bioactive compounds $[18,19]$. Consequently, the design of synthetic strategies to prepare this type of compounds and gaining knowledge regarding their occurrence in nature, are of increasing importance.

Recently, a detailed computational study of the mechanism of the Knoevenagel-Doebner reaction was reported [20], answering questions regarding the mechanism of the reaction and opening the door to new ones. Hydroxycinnamic acids are ubiquitous in plants, and it has been proposed that enzymatic decarboxylation may be responsible for vinylphenol production [21]. Besides the biocatalytic transformation, is it possible to perform the same reaction employing an organocatalyst? As an answer to this question, herein we describe a decarboxylation reaction of hydroxycinnamic acids under mild conditions. In addition, we report new experimental evidence for the previously proposed mechanism as well as the final outcome of the organocatalytic Knoevena-
gel-Doebner condensation.

\section{Experimental}

\subsection{General}

Chemical reagents were purchased from commercial sources and were used without further purification. Solvents were purified and dried by standard procedures. Reactions were monitored using thin layer chromatography (TLC) on silica gel (Kieselgel HF254) and visualized with UV light (254 nm) and $p$-anisaldehyde in acidic ethanolic solution. Flash column chromatography was performed using silica gel 60 (230 - 240 mesh). NMR $\left({ }^{1} \mathrm{H}\right.$ and $\left.{ }^{13} \mathrm{C}\right)$ spectra were carried out in a Bruker Advance DPX $400 \mathrm{MHz}$ equipment, at $30^{\circ} \mathrm{C}$ in the presence of TMS as internal standard. All products were previously reported and the spectroscopic data of all com- 
pounds were found to correspond with literature data.

\subsection{General Procedure for the Knoevenagel Condensation in Pyridine}

Malonic acid (1 g, $9.6 \mathrm{mmol}$ ) was dissolved in pyridine (10 mL, $124 \mathrm{mmol}$ ). Then, the substituted benzaldehyde (6.4 mmol) and piperidine $(0.24 \mathrm{~mL}, 2.4 \mathrm{mmol})$ were added. The mixture was refluxed for 2 h. After cooling, the solution was poured into ice water and concentrated $\mathrm{HCl}$ was added until $\mathrm{pH} 3$. The aqueous solution was extracted with ethyl acetate $(3 \times 20 \mathrm{~mL})$, dried over $\mathrm{Na}_{2} \mathrm{SO}_{4}$ and the solvent removed in vacuo. Purification by column chromatography over silica gel (7:3 hexane/ethyl acetate) yielded the corresponding 4-vinylphenol (for aldehydes 3a - 3c) or coumarin (for aldehydes 3d and 3e).

\subsection{General Procedure for the Reaction in Water}

Malonic acid (1 g, $9.6 \mathrm{mmol}$ ) was dissolved in water (10 $\mathrm{mL})$. Pyridine $(0.56 \mathrm{~mL}, 7.0 \mathrm{mmol})$, the substituted benzaldehyde $(6.4 \mathrm{mmol})$ and piperidine $(0.24 \mathrm{~mL}, 2.4$ mmol) were added. The mixture was refluxed for $2 \mathrm{~h}$. After cooling, the solution was poured into ice water and concentrated $\mathrm{HCl}$ was added until $\mathrm{pH} 3$. The aqueous solution was extracted with ethyl acetate $(3 \times 20 \mathrm{~mL})$, dried over $\mathrm{Na}_{2} \mathrm{SO}_{4}$ and the solvent removed in vacuo. Purification by column chromatography over silica gel (7:3 hexane/ethyl acetate) yielded the $\alpha, \beta$-unsaturated carboxylic acid, 4-vinylphenol and styrene dimer.

\subsection{Products}

Spectroscopic data of all compounds were found to match those in previous reports: 1a [12,13], 1b [21], 1c [13], 2a [12], 8d [22], 8e [23], 9a [24].

2-Methoxy-4-vinylphenol (1a)

${ }^{1} \mathrm{H}$ RMN (400 MHz, $\left.\mathrm{CDCl}_{3}\right) \delta_{\mathrm{H}}(\mathrm{ppm}) 3.85$ (s, 3H, $\left.\mathrm{OCH}_{3}\right), 5.11\left(\mathrm{dd}, 1 \mathrm{H}, J_{1}=10.8 \mathrm{~Hz}, J_{2}=0.9 \mathrm{~Hz}, \mathrm{CH}=\right.$ $\mathrm{CH}_{2}$ ), 5.57 (dd, $1 \mathrm{H}, J_{1}=17.6 \mathrm{~Hz}, J_{2}=0.9 \mathrm{~Hz}, \mathrm{CH}=\mathrm{CH}_{2}$ ), 5.77 (bs, $1 \mathrm{H}, \mathrm{OH}$ ), 6.62 (dd, $1 \mathrm{H}, J_{1}=17.6 \mathrm{~Hz}, J_{2}=10.8$ $\left.\mathrm{Hz}, \mathrm{CH}=\mathrm{CH}_{2}\right), 6.89$ (m, 3H, ArH). ${ }^{13} \mathrm{C} \mathrm{RMN}(100 \mathrm{MHz}$, $\left.\mathrm{CDCl}_{3}\right) \delta_{\mathrm{C}}(\mathrm{ppm}) 55.9,108.0,111.5,114.5,120.1,130.3$, 136.7, 145.6, 146.7 .

\section{4-Vinylphenol (1b)}

${ }^{1} \mathrm{H}$ RMN (400 MHz, acetone-d6) $\delta_{\mathrm{H}}(\mathrm{ppm}) 5.04$ (dd, $1 \mathrm{H}, J_{1}=10.9 \mathrm{~Hz}, J_{2}=1.1 \mathrm{~Hz}, \mathrm{CH}=\mathrm{CH}_{2}$ ), 5.59 (dd, $1 \mathrm{H}$, $\left.J_{1}=17.6 \mathrm{~Hz}, J_{2}=1.1 \mathrm{~Hz}, \mathrm{CH}=\mathrm{CH}_{2}\right), 6.65\left(\mathrm{dd}, 1 \mathrm{H}, J_{1}=\right.$ $\left.17.6 \mathrm{~Hz}, J_{2}=10.9 \mathrm{~Hz}, \mathrm{CH}=\mathrm{CH}_{2}\right), 6.81(\mathrm{~d}, 2 \mathrm{H}, J=6.7$ $\mathrm{Hz}, \mathrm{ArH}_{3}, \mathrm{ArH}_{5}$ ), 7.31 (d, 2H, $J=6.6 \mathrm{~Hz}, \mathrm{ArH}_{2}, \mathrm{ArH}_{6}$ ), 8.43 (bs, $\left.1 \mathrm{H}, \mathrm{OH}) .{ }^{13} \mathrm{C} \mathrm{RMN} \mathrm{(100} \mathrm{MHz,} \mathrm{CDCl}_{3}\right) \delta_{\mathrm{C}}(\mathrm{ppm})$
110.0, 115.3, 127.4, 129.3, 136.6, 157.4.

4-Vinylbenzene-1,2-diol (1c)

${ }^{1} \mathrm{H}$ RMN (400 MHz, acetone-d6) $\delta_{H}(\mathrm{ppm}) 5.02$ (dd, $\left.1 \mathrm{H}, J_{1}=10.9 \mathrm{~Hz}, J_{2}=1.1 \mathrm{~Hz}, \mathrm{CH}=\mathrm{CH}_{2}\right), 5.55(\mathrm{dd}, 1 \mathrm{H}$, $\left.J_{1}=17.6 \mathrm{~Hz}, J_{2}=1.1 \mathrm{~Hz}, \mathrm{CH}=C H_{2}\right), 6.60\left(\mathrm{dd}, 1 \mathrm{H}, J_{1}=\right.$ $\left.17.6 \mathrm{~Hz}, J_{2}=10.9 \mathrm{~Hz}, C H=\mathrm{CH}_{2}\right), 6.80\left(\mathrm{dd}, 2 \mathrm{H}, J_{1}=1.4\right.$ $\left.\mathrm{Hz}, J_{2}=0.9 \mathrm{~Hz}, \mathrm{Ar} H_{2}, \mathrm{Ar} H_{6}\right), 6.99$ (dd, $1 \mathrm{H}, J_{1}=1.4 \mathrm{~Hz}$, $J_{2}=0.9 \mathrm{~Hz}, \mathrm{ArH}_{5}$ ), 7.99 (bs, $\left.1 \mathrm{H}, \mathrm{OH}\right)$.

3-(4-Hydroxy-3-methoxyphenyl)-2-propenoic acid (ferulic acid) (2a)

${ }^{1} \mathrm{H}$ RMN (400 MHz, DMSO-d6) $\delta_{\mathrm{H}}(\mathrm{ppm}): 3.82$ (s, 3H, $\left.\mathrm{OCH}_{3}\right), 6.37$ (d, $\left.1 \mathrm{H}, J=15.9 \mathrm{~Hz},=\mathrm{CH}-\mathrm{COOH}\right), 6.80(\mathrm{~d}$, $\left.1 \mathrm{H}, J=8.1 \mathrm{~Hz}, \mathrm{ArH}_{5}\right), 7.09\left(\mathrm{dd}, 1 \mathrm{H}, J_{1}=8.2 \mathrm{~Hz}, J_{2}=1.9\right.$ $\mathrm{Hz}, \mathrm{ArH}_{6}$ ), 7.28 (d, $\left.1 \mathrm{H}, J=1.9 \mathrm{~Hz}, \mathrm{ArH}_{2}\right), 7.50$ (d, $1 \mathrm{H}, J$ $=15.9 \mathrm{~Hz}, \mathrm{CH}=\mathrm{CH}-\mathrm{COOH}), 9.57$ (bs, $1 \mathrm{H}, \mathrm{OH}) .{ }^{13} \mathrm{C}$ RMN (100 MHz, $\mathrm{CDCl}_{3}$ ) $\delta_{\mathrm{C}}(\mathrm{ppm})$ 56.1, 111.6, 116.0, 123.3, 126.2, 145.0, 148.4, 149.5, 168.5.

2H-Chromen-2-one (8d)

${ }^{1} \mathrm{H}$ RMN (400 MHz, acetone-d6) $\delta_{H}$ (ppm) 6.44 (d, 1H, $J=9.6 \mathrm{~Hz}, \mathrm{CH}=\mathrm{CH}-\mathrm{C}(\mathrm{O}) \mathrm{O}), 7.36\left(\mathrm{~m}, 2 \mathrm{H}, \mathrm{ArH} \mathrm{H}_{6}, \mathrm{Ar} H_{7}\right)$, 7.62 (m, 1H, ArH $\left.H_{5}\right), 7.71\left(\mathrm{~m}, 1 \mathrm{H}, \operatorname{Ar} H_{8}\right), 8.01$ (d, $1 \mathrm{H}, J=$ $9.6 \mathrm{~Hz}, \mathrm{CH}=\mathrm{CH}-\mathrm{C}(\mathrm{O}) \mathrm{O})$.

8-Methoxy-2H-chromen-2-one (8e)

${ }^{1} \mathrm{H}$ RMN (400 MHz, $\left.\mathrm{CDCl}_{3}\right) \delta_{H}(\mathrm{ppm}) 3.97$ (s, 3H, $\mathrm{OCH}_{3}$ ), 6.45 (d, $\left.1 \mathrm{H}, J=9.6 \mathrm{~Hz}, \mathrm{CH}=\mathrm{CH}-\mathrm{C}(\mathrm{O}) \mathrm{O}\right), 7.08$ (m, 2H, $\mathrm{ArH}_{5}, \mathrm{ArH}_{7}$ ), 7.22 (m, 1H, $\left.\mathrm{ArH} \mathrm{H}_{6}\right), 7.71$ (d, 1H, J $=9.6 \mathrm{~Hz}, \mathrm{CH}=C H-\mathrm{C}(\mathrm{O}) \mathrm{O}) \cdot{ }^{13} \mathrm{C} \mathrm{RMN} \mathrm{(100} \mathrm{MHz,}$ $\left.\mathrm{CDCl}_{3}\right) \delta_{C}(\mathrm{ppm})$ 56.2, 113.7, 116.9, 119.3, 124.3, 143.7, 147.2, 160.3, 191.0.

(E)-4,5'-(but-1-ene-1,3-diyl)bis(2-methoxyphenol) (9a)

$\left.{ }^{1} \mathrm{H} \mathrm{RMN} \mathrm{(400} \mathrm{MHz,} \mathrm{CDCl}_{3}\right) \delta_{H}(\mathrm{ppm}) 1.43$ (d, 3H, $J=$ $\left.7.0 \mathrm{~Hz}, \mathrm{CH}_{3}\right), 3.55\left(\mathrm{td}, 1 \mathrm{H}, J_{1}=7.0 \mathrm{~Hz}, J_{2}=6.6 \mathrm{~Hz}\right.$, $\mathrm{CH}-\mathrm{CH}_{3}$ ), 3.88 (s, 6H, 2xCH$)_{3}$ ), 5.52 (s, 1H, OH), 5.59 (s, $1 \mathrm{H}, \mathrm{OH}), 6.19$ (dd, $1 \mathrm{H}, J_{1}=15.8 \mathrm{~Hz}, J_{2}=6.5 \mathrm{~Hz}, \mathrm{CH}=$ $\left.\mathrm{CH}-\mathrm{CH}\left(\mathrm{CH}_{3}\right)\right), 6.31$ (dd, $1 \mathrm{H}, J_{1}=15.9 \mathrm{~Hz}, J_{2}=1.0 \mathrm{~Hz}$, $\left.\mathrm{CH}=\mathrm{CH}-\mathrm{CH}\left(\mathrm{CH}_{3}\right)\right)$, $6.76(\mathrm{~m}, 2 \mathrm{H}, \mathrm{ArH}) ; 6.92(\mathrm{~m}, 4 \mathrm{H}$, $\left.\mathrm{ArH}) .{ }^{13} \mathrm{C} \mathrm{RMN} \mathrm{(100} \mathrm{MHz,} \mathrm{CDCl}_{3}\right) \delta_{C}(\mathrm{ppm}) 21.4,42.2$, 55.9, 108.0, 109.9, 114.2, 114.3, 119.8, 128.0, 130.2, 133.3, 137.8, 143.9, 145.0, 146.4, 146.6.

\section{Results and Discussion}

\subsection{Knoevenagel Condensation: Mechanistics Insights}

A detailed proposed mechanism that agrees with experimental information is shown in Figure 3. This mechanism, based on previously suggested ones [12,13], includes new information, such as the role of the organocatalyst in the entire process. In particular, the contributing effect of the catalyst to the key decarboxylation step.

Even though the Knoevenagel reaction has been em- 

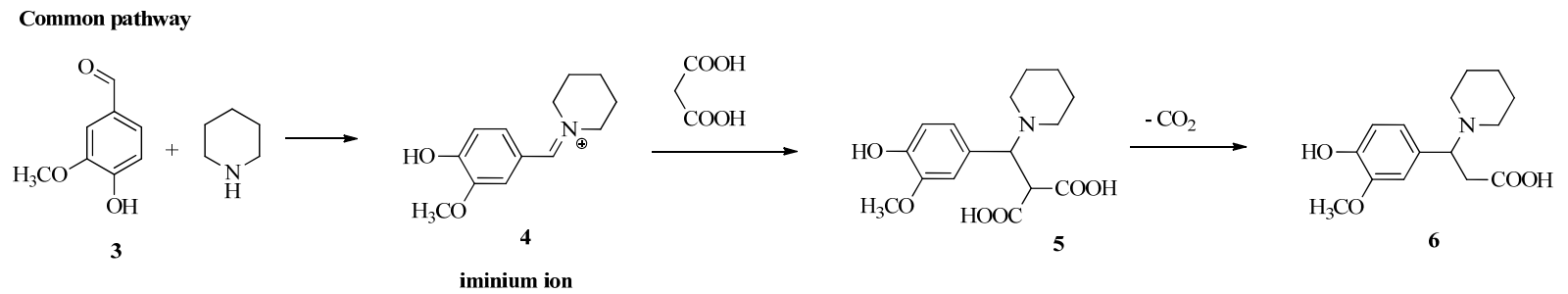

Route 1
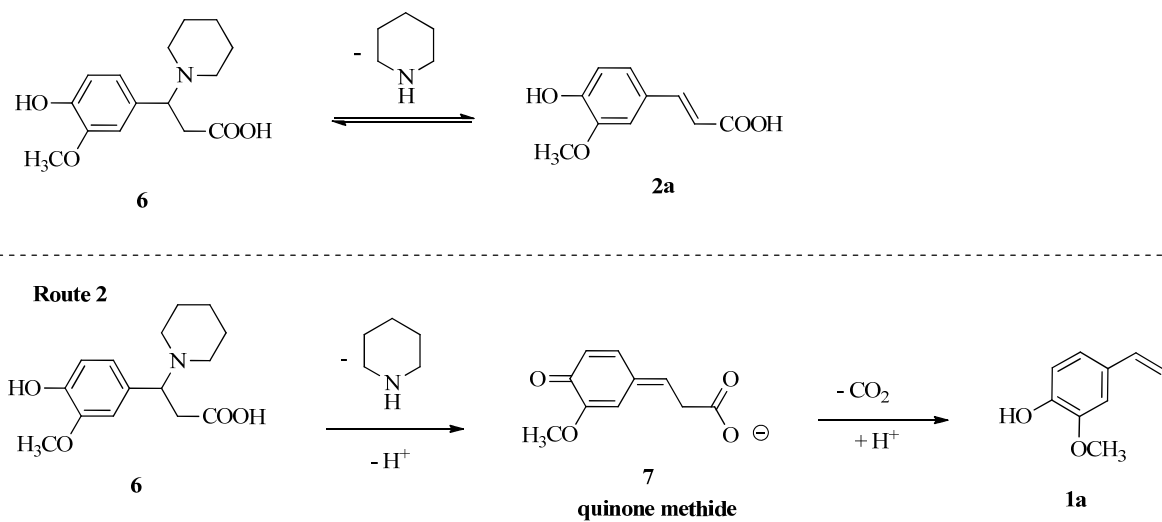

$1 \mathbf{a}$

Figure 3. Proposed mechanism for the preparation of ferulic acid and 2-methoxy-4-vinylphenol.

ployed to obtain cinnamic acid and derivatives, both the reaction and work-up conditions previously reported are different than those described in this work. Simpson and coworkers stated that the styrene formation took place only when a proper substrate (2- or 4-hydroxybenzaldehyde) was used jointly with toluene for removing the pyridine by distillation in vacuo [12]. In this work, we found that quenching the reaction with acid works as well. Therefore, contrary to previously described mechanism, we demonstrate that styrene formation does not depend on the work-up conditions, and took place before the work-up.

We analyzed the outcome of the Knoevenagel-Doebner condensation of 2-hydroxy- and 4-hydroxy substituted benzaldehydes (Figure 4 and Table 1), employing a lower load of catalyst (ten times) than previously described one and quenching the reaction with $\mathrm{HCl}$.

The load of catalyst was evaluated, and we found that 1:0.4 corresponds to the optimum vanillin:piperidine ratio (results not shown).

From these results it is evident that only 4-hydroxysubstituted aldehydes lead to the corresponding vinylphenol. Presumably, a quinone methide intermediate can be obtained for both 2-hydroxy and 4-hydroxy substituted benzaldehydes (Figure 5). In spite of that, the stability and reactivity of ortho- and para-quinone methides are not exactly the same.

Quinone methides are common reactive intermediates extensively employed by nature, particularly in the mechanism of action displayed by a variety of bioactive compounds $[25,26]$. The stability of such intermediates is essential to evaluate the outcome of the reaction. Ortho-quinone methides are less stable (ca. 2 times) than the corresponding para- isomers [27], and thus the formation of the latter can be favored. Taking this into account, subsequent decarboxylation reaction is also favored, and the 4-vinylphenol is then afforded. When the reactant aldehyde is 2-hydroxy substituted, a lower energy pathway than the formation of the quinone methide intermediate is available, and a different outcome for the reaction is observed. 2-Hydroxybenzaldehyde (entry 4, Table 1) and 2-hydroxy-3-methoxybenzaldehyde (entry 5, Table 1) afforded a coumarin derivative.

Coumarin (1,2-benzopyrone) is a secondary plant metabolite with a pleasant flavor, which use as food flavoring

Table 1. Products obtained for the Knoevenagel-Doebner condensation of aromatic aldehydes and malonic acid.

\begin{tabular}{cccc}
\hline & \multicolumn{2}{c}{ Product distribution $^{\mathrm{a}}$} \\
\hline Entry & Aldehyde & Cinnamic acid (2) (\%) & Styrene (1) (\%) \\
1 & 3a & 0 & 80 \\
2 & 3b & Traces & 60 \\
3 & 3c & 0 & 59 \\
4 & 3d & 0 & $\mathbf{1 d ~ ( 0 \% ) ~}+\mathbf{8 d}(15 \%)$ \\
5 & 3e & Traces & 1e (Traces) $+\mathbf{8 e}(20 \%)$ \\
\hline
\end{tabular}

${ }^{\mathrm{a}}$ Remaining percentage corresponds to starting material. 


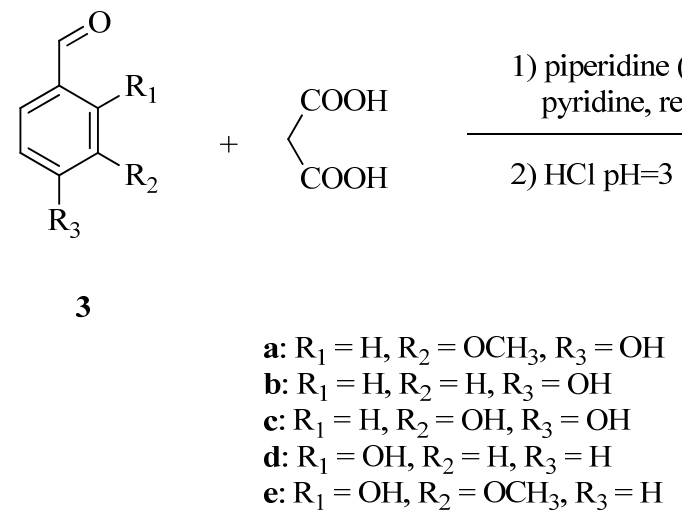<smiles>[R]c1ccc(/C=C/C(=O)O)c([R])c1[R]</smiles>

2<smiles>COc1cccc2ccc(=O)oc12</smiles>

Figure 4. Conversion of 2- and 4-hydroxy-substituted aromatic aldehydes into cinnamic acids, styrene derivatives and coumarins.<smiles>O=C(O)CC=C1C=CC=CC1=O</smiles>

ortho quinone methide<smiles>O=C1C=CC(=CCC(=O)O)C=C1</smiles>

para quinone methide<smiles>C=Cc1ccccc1O</smiles>

ortho vinylphenol

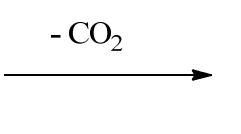

para vinylphenol

Figure 5. Quinone methide intermediates in the double decarboxylative Knoevenagel-Doebner reaction.

substance was prohibited due to the discovery of its hepatotoxic properties in laboratory animals. Is has been described that coumarin is present in cinnamon, and therefore is of interest to identify factors influencing coumarin levels in this important spice [28]. Cinnamon contains also other volatile constituents such as cinnamic acids and cinnamaldehyde among others. The reaction reported herein may be of importance for understanding observed changes in coumarin levels during storage.

The fact that only 4-hydroxybenzaldehydes undergo a second decarboxylation yielding the corresponding 4-vinylphenol reinforces the idea that a quinone methide is a key intermediate in this reaction. As shown in Figure 3, when using piperidine as organocatyst, the Knoevenagel reaction is initiated by formation of iminium ion 4. This has been proposed as an activation mode for reactions organocatalyzed by secondary amines (such as piperidine, pyrrolidine or proline) [29]. According to route 1 in Figure 3, the $\beta$-amino acid $\mathbf{6}$ can undergo a $\beta$-elimination reaction leading to ferulic acid. Also, as shown in Route 2, 1,6-elimination of piperidine leads to the quinone methide 7 . In the presence of a base, the quinone methide is afforded upon deprotonation of the phenol group. The formation of this key intermediate is the driving force for the second decarboxylation leading to the product 1a after a final protonation during the work-up. When the phenolic group is absent or protected, the quinone methide cannot be obtained and thus no further decarboxylation takes place, and the $\alpha, \beta$-unsaturated carboxylic acid is obtained through Route 1 .

\subsection{Organocatalyzed Decarboxylation of Ferulic Acid}

As shown in Table 1, the corresponding 4-hydroxysubstituted cinnamic acid is not obtained. One possible explanation is that Route 2 corresponds to the favored pathway under employed conditions, and therefore $\mathbf{2}$ is simply not obtained. On the other side, if the 4-hydroxysubstituted cinnamic acid $\mathbf{2}$ is produced through a reversible reaction (Route 1), the second decarboxylation reaction can take place even if the acid is afforded. It has been argued that the formation of the trans-cinnamic acid is effectively non-reversible [12]. However, highlevel theoretical calculations showed that under employed conditions, Route 1 is essentially reversible [20]. 
To this end, we envisioned an experiment that can demonstrate the role of a secondary amine in the decarboxylation leading to 4-vinylphenol. When using the Knoevenagel conditions mentioned before, with ferulic acid as reactant, 2-methoxy-4-vinylphenol 1a was obtained as a single product. Moreover, if this reaction is performed under the same conditions but without piperidine, unchanged ferulic acid is recovered. Herein we report the decarboxylation of ferulic acid 2a to vinylphenol 1a under mild conditions, involving a 1,4-addition of piperidine yielding intermediate 6. Most of available protocols for decarboxylation of cinnamic acid derivatives involve the use of strong conditions, such as toxic quinoline-metal salts [30].

Intermediate 6 suffer a 1,6-elimination of piperidine affording the key quinone methide $\mathbf{8}$, which undergoes a decarboxylation reaction leading to the styrene derivative 1a (Figure 6).

This result agrees with the mechanistic role proposed for piperidine, suggesting that intermediate $\mathbf{6}$ facilitates the final decarboxylation reaction leading to the 4-vinylphenol 1a.

We also propose that this reaction is relevant in food chemistry. Phenolic styrenes have strong flavours and because of that, their presence sometimes is a limitation for the use of the product in foods or beverages. Barley and wheat malts are the most important raw materials for beer production. In those grains, ferulic acid is present and it is known that during brewing, 2-methoxy-4vinylphenol 1a is produced [31-33].

Until now, thermal or enzymatic decarboxylation of ferulic acid, were proposed as the responsible mechanisms for the production of 4-vinylphenol derivatives. We suggest that 4-vinylphenol is produced also through the pathway showed in Figure 6, using a readily available secondary amine, such as proline, which is present in wheat and barley [34].

Thus, under malting and brewing condition, proline (organocatalyst) adds to ferulic acid affording the corresponding $\beta$-amino acid. Further amine and $\mathrm{CO}_{2}$ elimination leads to 2-methoxy-4-vinylphenol production. In fact, when attempting the decarboxylation of ferulic acid employing proline as organocatalyst, the reaction was complete, leading to 2-methoxy-4-vinylphenol as a single product.

Such processes in natural environments are actually performed in aqueous media. Therefore, the choice of solvent may be critical. The Knoevenagel-Doebner reaction of aromatic aldehydes has been performed employing different solvents or even under solvent-free conditions [3,12].

\subsection{Vinylphenol Dimerization in Water}

Both the elimination step to get ferulic acid and the decarboxylation leading to 4-vinylphenol, are expected to be affected by solvent properties, such as polarity. Thus, we performed the reaction in water. One can expect that increasing the dielectic constant will raise both the global conversion and the 2-methoxy-4-vinylphenol/ferulic acid ratio. Contrary to these assumptions, when performing the reaction in water (dielectric constant of water $=80.1$, dielectric constant of pyridine $=13.26$ ) [35] a totally different result was obtained.

Ferulic acid and 2-methoxy-4-vinylphenol were obtained, but in different amounts than those obtained in pyridine (18\% and $8 \%$ of yield, respectively). In addition, during the reaction we observed the formation of a new compound 9a (67\% of yield), with a ${ }^{1} \mathrm{H}$ NMR showing a clear ABX system and a trans double bond (Figure 7). Spectroscopic data is in agreement with the proposed structure.

The structure of 9a immediately suggests that this product can be obtained through a dimerization of 2-methoxy-4-vinylphenol. Dimerization of styrene derivatives has been reported by several authors [36-40].

In order to confirm this hypothesis, we performed the reaction in water under the same conditions as before, but employing 2-methoxy-4-vinylphenol 1a as substrate. After 2 hours of refluxing, the product 9a was obtained as a single product. If the reaction time is extended, polar polymeric products are formed, while $\mathbf{9 a}$ is consumed.

When considering the relative amounts of acid (malonic acid) and bases (pyridine/piperidine) employed, one can see that malonic acid is present in a small excess.<smiles>COc1cc(/C=C/C(=O)O)ccc1O</smiles>

ferulic acid, 2a
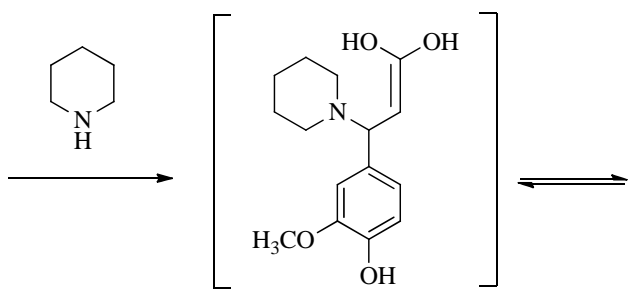
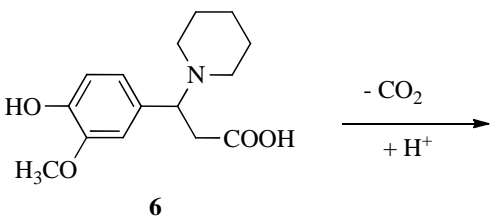<smiles>C=Cc1ccc(O)c(OC)c1</smiles>

$1 \mathbf{a}$

Figure 6. Organocatalyzed decarboxylation of ferulic acid. 
<smiles>COc1cc(C([18F])=C([18OH])C(C)(C)c2ccc(O)c(OC)c2)ccc1O</smiles>

9a

Figure 7. 2-Methoxy-4-vinylphenol dimer obtained in water.<smiles>[R]c1ccc(C=O)c([R])c1[R]</smiles>

3

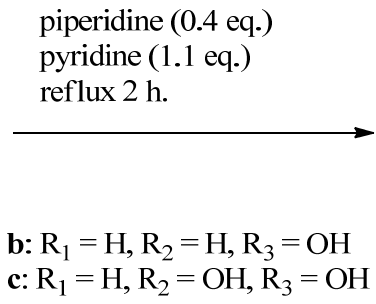

Consequently, we proposed an acid catalyzed mechanism for the formation of vinylphenol dimer. 2-Methoxy4-vinylphenol is first protonated affording a stabilized carbocation, which undergo cationic dimerization with a second vinylphenol molecule. Finally, elimination of a proton yields the dimer $\mathbf{9 a}$.

In order to confirm this proposal, we performed the reaction employing only vinylphenol 1a (1 eq.) and malonic acid (0.02 eq.) in water. Such conditions reproduce the relative excess of malonic acid in the original<smiles>[R3]c1ccc(C=C)c([R])c1[18OH]</smiles>
1<smiles>[R3]c1ccc(/C=C/C(C)c2ccc([R3])c([R])c2[R])c([R])c1[R3]</smiles>
9

Figure 8. Knoevenagel condensation of 4-hydroxyaldehydes in water.

reaction. Under these conditions, dimer 9a was obtained after 2 hours under reflux. When changing malonic acid $(\mathrm{pKa}=2.85)[35]$ for salicylic acid $(\mathrm{pKa}=2.98)$ [35] the same reaction was observed. Therefore, in the presence of a weak organic acid, 3-methoxy-4-vinylphenol dimerizes.

Finally, attempting to extend the scope of the styrene dimerization process, we performed the same reaction employing those aldehydes different from vanillin, which in the first place lead to vinylphenol derivatives (i.e. 4-hydroxy substituted aldehydes) (Figure 8 and Table 2).

After two hours of refluxing, styrene dimer was obtained, though in a lower yield than that observed when vanillin was the reactant aldehyde. Therefore, this reaction becomes more important in the latter case.

To summarize, during the Knoevenagel condensation of vanillin and malonic acid in water, ferulic acid is first obtained. Subsequent decarboxylation of ferulic acid leads to vinylphenol 1a. Once the styrene derivative is afforded, a self-addition reaction takes place producing the dimer 9a. This reaction is also of importance in food chemistry. Cinnamic acid derivatives are frequently found in fruits and vegetables. Heat treatment can trigger cinnamic acids decarboxylation to vinylphenols, and dimerization of vinylphenol can further modify organoleptic properties of juices, fruits and beverages, even when obtained in small amounts [41].

\section{Conclusions}

In this work we delineate the mechanism of the organo
Table 2. Products obtained for the Knoevenagel condensation of 4-hydroxy-substituted aldehydes and malonic acid in water.

\begin{tabular}{cccc}
\hline & & \multicolumn{3}{c}{ Product distribution $^{\mathrm{a}}$} \\
\hline Entry & Aldehyde & Styrene (1) (\%) & Styrene dimer (9) (\%) \\
1 & 3b & 15 & 5 \\
2 & 3c & 5 & 2 \\
\hline
\end{tabular}

${ }^{a}$ remaining percentage corresponds to starting material.

catalyzed Knoevenagel-Doebner reaction, based on experimental evidences on the role of catalyst and solvent. Also, we report for the first time the decarboxylation of ferulic acid under mild conditions and the dimerization of vinylphenol in water. This insight on the mechanism allows to tuning the outcome of Knoevenagel reaction.

Even though dimerization of styrene derivatives has been reported, in all cases the dimer was obtained when treating styrene either with strong Brönsted or Lewis acids. Here, we report the dimerization under totally different conditions. It is important to take into account that several natural amines and amino acids can catalyze the decarboxylation of cinnamic acids into vinylphenol derivatives, and the subsequent dimerization of the latter can take place. This has to be considered in food chemistry to avoid obtaining undesired products.

\section{Acknowledgements}

Lindbergh Foundation (USA), PEDECIBA (Uruguay) and ANII (Uruguay) are gratefully acknowledged for financial support.

\section{References}

[1] R. Hatfield and W. Vermerris, "Lignin Formation in 
Plants. The Dilemma of Linkage Specificity," Plant Physiology, Vol. 126, No. 4, 2001, pp. 1351-1357. doi:10.1104/pp.126.4.1351

[2] A. -M. Boudet, "Lignins and Lignification: Selected Issues," Plant Physiology and Biochemistry, Vol. 38, No. 1-2, 2000, pp. 82-96. doi:10.1016/S0981-9428(00)00166-2

[3] G. Kaupp, M. R. Naimi-Jamal and J. Schmeyers, “Solvent-Free Knoevenagel Condensations and Michael Additions in the Solid State and in the Melt with Quantitative Yield,” Tetrahedron, Vol. 59, No. 21, 2003, pp. 37533760. doi:10.1016/S0040-4020(03)00554-4

[4] B. List, A. Doehring, M. T. H. Fonseca, A. Job and R. Rios Torres, "A Practical, Efficient, and Atom Economic Alternative to the Wittig and Horner-Wadsworth-Emmons Reactions for the Synthesis of (E)-Unsaturated Esters from Aldehydes," Tetrahedron, Vol. 62, No. 2-3, 2006, pp. 476-482. doi:10.1016/j.tet.2005.09.081

[5] M. Tanaka, O. Oota, H. Hiramatsu and K. Fujiwara, "The Knoevenagel Reactions of Aldehydes with Carboxy Compounds. I. Reactions of p-Nitrobenzaldehyde with Active Methine Compounds," Bulletin of the Chemical Society of Japan, Vol. 61, No. 7, 1988, pp. 2473-2479. doi:10.1246/bcsj.61.2473

[6] K. A. Ahrendt, C. J. Borths and D. W. C. MacMillan, "New Strategies for Organic Catalysis: The First Highly Enantioselective Organocatalytic Diels-Alder Reaction," Journal of the American Chemical Society, Vol. 122, No. 17, 2000, pp. 4243-4244. doi:10.1021/ja000092s

[7] P. I. Dalko and L. Moisan, "Enantioselective Organocatalysis,” Angewandte Chemie International Edition, Vol. 40, 2001, pp. 3726-3748. doi:10.1002/1521-3773

[8] K. Juhl and K. A. Jorgensen, "The First Organocatalytic Enantioselective Inverse-Electron-Demand Hetero-DielsAlder Reaction," Angewandte Chemie International Edition, Vol. 42, No. 13, 2003, pp. 1498-1501. doi:10.1002/anie.200250652

[9] D. W. C. MacMillan, "The Advent and Development of Organocatalysis,” Nature, Vol. 455, 2008, pp. 304-308. doi:10.1038/nature07367

[10] M. L. Derrudi, F. Geymonat, V. Aldabalde, D. Gamenara, G. Seoane and P. S. Méndez, "Síntesis Organocatalítica Eficiente de Precursors de Fenilglicidatos Funcionalizados,” XVII-Simposio Nacional de Química Orgánica, Mendoza, 2009.

[11] F. Geymonat, V. Aldabalde, M. L. Derrudi, D. Gamenara, G. Seoane and P. S. Méndez, "Efecto de las Condiciones en el Curso de la Reacción Descarboxilativa de Knoevenagel,” XVII-Simposio Nacional de Química Orgánica, Mendoza, 2009.

[12] C. J. Simpson, M. J. Fitzhenry and N. P. J. Stamford, "Preparation of Vinylphenols from 2- and 4-Hydroxybenzaldehydes," Tetrahedron Letters, Vol. 46, No. 40, 2005, pp. 6893-6896. doi:10.1016/j.tetlet.2005.08.011

[13] A. K. Sinha, A. Sharma and B. P. Joshi, "One-Pot Two-Step Synthesis of 4-Vinylphenols from 4-Hydroxy Substituted Benzaldehydes under Microwave Irradiation:
A New Perspective on the Classical Knoevenagel-Doebner Reaction,” Tetrahedron, Vol. 63, No. 4, 2007, pp. 960965. doi:10.1016/j.tet.2006.11.023

[14] J. M. Ames and G. Macleod, "Volatile Components of Okra,” Phytochemistry, Vol. 29, No. 4, 1990, pp. 12011207.

[15] H. Y. Chung, "Volatile Flavor Components in Red Fermented Soybean (Glycin Max) Curds," Journal of Agricultural and Food Chemistry, Vol. 48, No. 5, 2000, pp. 1803-1809. doi:10.1021/jf991272s

[16] P. Pihlsgård, M. Larsson, A. Leufvén and H. Lingnert, "Volatile Compounds in the Production of Liquid Beet Sugar," Journal of Agricultural and Food Chemistry, Vol. 48, No. 10, 2000, pp. 4844-4850. doi:10.1021/jf000514h

[17] D. Janes, D. Kantar, S. Kreft and H. Prosen, "Identification of Buckwheat (Fagopyrum Esculentum Moench) Aroma Compounds with GC-MS,” Food Chemistry, Vol. 112, No. 1, 2009, pp. 120-124. doi:10.1016/j.foodchem.2008.05.048

[18] R. Cong, R. Pelton, P. Russo and G. Doucet, "Factors Affecting the Size of Aqueous Poly (Vinylphenol-co-Potassium Styrenesulfonate)/Poly(Ethylene Oxide) Complexes," Macromolecules, Vol. 36, No. 1, 2002, pp. 204209. doi:10.1021/ma020965y

[19] S. N. Aslam, P. C. Stevenson, S. J. Phythian, N. C. Veitch and D. R. Hall, "Synthesis of Cicerfuran, an Antifungal Benzofuran, and Some Related Analogues," Tetrahedron, Vol. 62, No. 17, 2006, pp. 4214-4226.

doi:10.1016/j.tet.2006.02.015

[20] E. Bermúdez, O. N. Ventura and P. Saenz Méndez, "Mechanism of the Organocatalyzed Decarboxylative Knoevenagel-Doebner Reaction. A Theoretical Study," The Journal of Physical Chemistry A, Vol. 114, No. 50, 2010, pp. 13086-13092. doi:10.1021/jp109703f

[21] M. Takemoto and K. Achiwa, "Synthesis of Styrenes through the Decarboxylation of Trans-Cinnamic Acids by Plant Cell Cultures," Tetrahedron Letters, Vol. 40, 1999, pp. 6595-6598. doi:10.1016/S0040-4039(99)01281-2

[22] K. Zeitler and C. A. Rose, "An Efficient Carbene-Catalyzed Access to 3,4-Dihydrocoumarins," The Journal of Organic Chemistry, Vol. 74, No. 4, 2009, pp. 1759-1762. doi:10.1021/jo802285r

[23] P. K. Upadhyay and P. Kumar, “A Novel Synthesis of Coumarins Employing Triphenyl([Alpha]-Carboxymethylene)Phosphorane Imidazolide as a C-2 Synthon,” Tetrahedron Letters, Vol. 50, No. 2, 2009, pp. 236-238. doi:10.1016/j.tetlet.2008.10.133

[24] G. P. Rizzi and L. J. Boekley, “Observation of EtherLinked Phenolic Products during Thermal Degradation of Ferulic Acid in the Presence of Alcohols,” Journal of Agricultural and Food Chemistry, Vol. 40, No. 9, 1992, pp. 1666-1670. doi:10.1021/jf00021a037

[25] Q. Zhou and K. D. Turnbull, "Phosphodiester Alkylation with a Quinone Methide," The Journal of Organic Chemistry, Vol. 64, No. 8, 1999, pp. 2847-2851. doi:10.1021/jo9823745 
[26] R. W. Van De Water and T. R. R. Pettus, "O-Quinones Methides: Intermediates Underdeveloped and Underutilized in Organic Synthesis,” Tetrahedron, Vol. 58, 2002, pp. 5367-5405. doi:10.1016/S0040-4020(02)00496-9

[27] G. Bouchoux, "Heats of Formation and Protonation Thermochemistry of Gaseous Benzaldehyde, Tropone and Quinone Methides," Chemical Physics Letters, Vol. 495, No. 4-6, 2010, pp. 192-197. doi:10.1016/j.cplett.2010.07.008

[28] F. Woehrlin, H. Fry, K. Abraham and A. Preiss-Weigert, "Quantification of Flavoring Constituents in Cinnamon: High Variation of Coumarin in Cassia Bark from the German Retail Market and in Authentic Samples from Indonesia," Journal of Agricultural and Food Chemistry, Vol. 58, 2010, pp. 10568-10575. doi:10.1021/jf102112p

[29] B. List, "Proline-Catalyzed Asymmetric Reactions," Tetrahedron, Vol. 58, 2002, pp. 5573-5590. doi:10.1016/S0040-4020(02)00516-1

[30] S. M. Fleming, T. A. Robertson, G. J. Langley and T. D. H. Bugg, "Catalytic Mechanism of a C-C Hydrolase Enzyme: Evidence for a Gem-Diol Intermediate, Not an Acyl Enzyme," Biochemistry, Vol. 39, No. 6, 2000, pp. 15221531. doi:10.1021/bi9923095

[31] S. Coghe, K. Benoot, F. Delvaux, B. Vanderhaegen and F. R. Delvaux, "Ferulic Acid Release and 4-Vinylguaiacol Formation during Brewing and Fermentation: Indications for Feruloyl Esterase Activity in Saccharomyces Cerevisiae," Journal of Agricultural and Food Chemistry, Vol. 52, No. 3, 2004, pp. 602-608. doi:10.1021/jf0346556

[32] N. Vanbeneden, F. Gils, F. Delvaux and F. R. Delvaux, "Formation of 4-Vinyl and 4-Ethyl Derivatives from Hydroxycinnamic Acids: Occurrence of Volatile Phenolic Flavour Compounds in Beer and Distribution of Pad1Activity among Brewing Yeasts,” Food Chemistry, Vol. 107, No. 1, 2008, pp. 221-230. doi:10.1016/j.foodchem.2007.08.008

[33] L. Du and P. Yu, "Effect of Barley Variety and Growth
Year on Ferulic and Para-Coumaric Acids, and Their Ration in the Seed and Hull," Cereal Research Communications, Vol. 38, No. 4, 2010, pp. 521-532. doi:10.1556/CRC.38.2010.4.9

[34] L. Szabados and A. Savouré, "Proline: A Multifunctional Amino Acid," Trends in Plant Science, Vol. 15, 2009, pp. 89-97. doi:10.1016/j.tplants.2009.11.009

[35] D. R. Lide, "CRC Handbook of Chemistry and Physics," CRC Press, Boca Raton, 2003-2004.

[36] B. B. Corson, J. Dorsky, J. E. Nickels, W. M. Kutz and H. I. Thayer, "Dimerization of Styrene in the Presence and Absence of Solvent," The Journal of Organic Chemistry, Vol. 19, No. 1, 1954, pp. 17-26. doi:10.1021/jo01366a004

[37] M. J. Rosen, "Studies of the Dimerization of Styrene in Aqueous Sulfuric Acid," The Journal of Organic Chemistry, Vol. 18, No. 12, 1953, pp. 1701-1705. doi:10.1021/jo50018a012

[38] B. B. Corson, W. J. Heintzelman, H. Moe and C. R. Rousseau, "Reactions of Styrene Dimers," The Journal of Organic Chemistry, Vol. 27, No. 5, 1962, pp. 1636-1640. doi:10.1021/jo01052a036

[39] T. Higashimura, M. Hiza and H. Hasegawa, "Catalytic Difference between Oxo Acids and Metal Halides in the Cationic Oligomerization of Styrene," Macromolecules, Vol. 12, No. 2, 1979, pp. 217-222. doi:10.1021/ma60068a010

[40] J. Peng, J. Li, H. Qiu, J. Jiang, K. Jiang, J. Mao and G. Lai, "Dimerization of Styrene to 1,3-Diphenyl-1-butene Catalyzed by Palladium-Lewis Acid in Ionic Liquid,” Journal of Molecular Catalysis A: Chemical, Vol. 255, No. 1-2, 2006, pp. 16-18. doi:10.1016/j.molcata.2006.03.058

[41] B. Fallico, M. C. Lanza, E. Maccarone, C. Nicolosi Asmundo and P. Rapisarda, "Role of Hydroxycinnamic Acids and Vinylphenols in the Flavor Alteration of Blood Orange Juices," Journal of Agricultural and Food Chemistry, Vol. 44, No. 9, 1996, pp. 2654-2657. doi:10.1021/jf9503319 